\title{
Inheritance and Innovation: Establishment of Sino-Central Asia Artistic Exchange Mechanism
}

\author{
Ziqiu Wei ${ }^{1}$, Yanling $\mathrm{Li}^{2}$ \\ ${ }^{1}$ College of International Cultural Exchange of Northwest Normal University, Lanzhou Gansu, \\ 730070, Chian \\ ${ }^{2}$ Lanzhou Institute of Technology School of Art and Design, Lanzhou Gansu, 730000, Chian
}

Key words: Silk Road, Central Asia, Artistic exchange mechanism.

\begin{abstract}
Artistic exchange is an important way for "communication" between China and Central Asia. The artistic exchange between China and Central Asia has a long history and rich connotations. In the new times, we are supposed to build artistic brands, perfect the art industry system, enrich artistic exchange patterns, promote the exchange in respect of width and depth, and establish a scientific and effective two-way exchange mechanism based on the inter-subject communication theory and interactive cooperation theory and according to the characteristics of Central Asian countries.
\end{abstract}

\section{Introduction}

Central Asia is an important node in the Silk Road economic zone, and an important region to which China opens itself westwardly. The history of exchange between China and Central Asia is long and full of ups and downs. Comparing with East Asia and Southeast Asia, the "westward" communication of Chinese culture has been appearing to be unsatisfactory. Since the Middle Tang Dynasty, the ruling of Islam had been established in this region, and it became gradually estranged from Chinese Confucian Civilization. At the present time, although Central Asian countries are adjacent to China in the west, they seldom communicate with China. Therefore, to develop a long-term amicable relation with Central Asia, it is urgent that both sides should make greater efforts to understand and communicate with each other. With the constant change of political relations, the proposal of different economic appeals, and totally different religious cultures, how can China communicate with Central Asia in an amicable way? Artistic exchange is an important way to overcome the misunderstanding of people's culture.

\section{Rich Historical Connotations of Artistic Exchange between China and Central Asia}

Art is one of the most expressive cultures. It is usually independent from realistic interests, and is helpful to reach beyond national, ethnical, political, religious, linguistic and literal misunderstandings and limitations and dispel prejudice and conflict. Thus, it is highly acceptable. Even in an extreme war, artistic communication can be realized via the forcible promotion of the winner and the active absorption and unconscious infusion of both sides. This is the "magic power" of art. On the other hand, showing curiosity about different cultures is almost the gene in common of all mankind. Every country and nation have their own unique culture and art, which are attractive to "others". Being adjacent to each other, both Chinese and Central Asians are curious about, have imagination about and have expectation on each other, and long for understand and communicate with each other. Especially, since China have had a good understanding of other regions of Asia, it strongly desire to learn about Central Asia. It is helpful to unconsciously shorten the gap among countries by going over the traditional classical arts having a long history, and promoting vivid and fresh modern arts. It is an effective way to enhance the understanding and intimity among the countries via artistic and cultural exchange. 
As early as the late Warring States Period in the third century BC, the plastic arts of animal print prevailing in Northern China absorbed the characteristics of Sarmatian Culture of Central Asia (referred to as "Aorsoi" in Chinese documents), including patterning zoomorphic design, geometric pattern, plant pattern, etc. In the period of two Han Dynasties, musical dance of spectacle and circus were introduced into China mainland from the western regions successively. In 384AD, Lyu Guang, the founder of Later Liang, brought back a large quantity of dancers and musicians when coming back from the battle in the western regions. He integrated Qiuci music with music and dance in the central plains in Hexi area, to form the unique His Liang Yeh. As recorded in the History of Sui Dynasty-Music Record: "Western Liang originated from the last generation of Fus; Lyu Guang, Juqu Mengxun, et al. occupied the Liang state, and transformed Qiuci music, which was called Ch'in Han Chi. Emperor Taiwu of Nothern Wei suppressed the Hexi area and obtained it, and called it Hsi Liang Yeh, which was called Guo Ji in the Western Wei and Northern Zhou." (1); in the Han and W ei dynasties, Buddhism was introduced into China via the western regions. The Buddhism art in the western regions cover temple architecture, grotto, mural art, figure of Buddha, and so on. The material application in Buddhism art also was introduced eastward, and impacted China. In the Tang Dynasty from the sixth century to the ninth century AD, the western region art was popular in Chang'an, became an important element of Sui and Tang's cultural ethos. At that time, Central Asian countries offered or presented dancing girls to the Tang reign, and the Huteng Dance played by men also was fashionable. Quite a number of Tang poems are about Huteng Dance and Huxuan Dance. In the 13th century AD, with Mongolians' conquest of the west, a large number of Central Asian craftsmen, religious people, and artists moved eastward, when the artistic exchange between China and the western regions reached the peak, especially in architecture and music. For example, Hobus, a musical instrument introduced from "the Hui nation" was all the mode in the Yuan Dynasty. As recorded in Yang Yu's Shan Ju Xin Yu: "Hobus made of wrought iron is rare in the world, and is one of the top-grade musical instruments in the Hui nations, which is delicately manufactured" (2). The Komuz of Khalkhas in Xinjiang and the Hubo of Nakhi People in Yunnan both were developed from Hobus.

China's traditional arts also have had an impact on Central Asia. In the Tang Dynasty, many Central Plain painters moved to the western regions, bringing Central Plain painting art there. The Paris polyphylla near Casinia, the capital of Koshana[1], bears a portrait of an ancient Chinese emperor, of which the painting style and content are similar to that of the 13 portraits of emperors of Yan Liben. Foreign patterns (from Byzantium, Iran, Turkic, and China) also can be seen on metalwares" (5). Central Plain statuary art al so has had an impact on Central Asia. The Silk Road was opened mainly out of political and military objectives initially. After the wars ended, the common desire of the countries along the road for economic and cultural exchanges became the developing motive of the road. Since then, the achievements of religion, dance, music, painting, and literature in various regions were spread and diffused via the Silk Road, which were continuously exploited and utilized by later generations, and became an inexhaustible source of inspiration of artists.

Of course, the most active exchange along the Silk Road is about material culture, but material exchange is not completely independent of artistic exchange. Up to now, some well-known flat wares are still called "china". Concerning manufacturing treasures, Chinese people are known for ingenuity and excellent craftsmanship as always......Chinese people's craftsmanship in statuary art is awfully outstanding, and are excellent in carving and painting......"(7)The demand for and assessment of foreign solid state cultures reflect their attitudes towards the national spirit and aesthetic ideas implied thereby.

\section{Current Situation of and Problems in Artistic Exchange between China and Central Asia}

In recent years, some achievements have been preliminarily made in artistic exchange between China and Central Asia, and a good momentum has been formed. In the Vision and Actions on Jointly Building Silk Road Economic Belt and 21st-century Maritime Silk Road, Xinjiang was determined as the "core area of the Silk Road Economic Belt", and it was emphasized to "take the comprehensive 
economic and cultural advantage of Shaanxi and Gansu and the ethnical cultural advantage of Ningxia and Qianhai" to form a cultural and educational exchange base opened to Central Asian, South Asian and Western Asian countries. The making of these policies has established a broad platform for international cultural and artistic exchanges, and full consideration of geography, religion, and culture has been taken.

Central Asian countries often send arts group to China for performance. China and Tajikistan signed the Agreement of the Cultural Cooperation between the Tajikistan Republic and the People's Republic of China in Duschanbe in December 1993, and the Cultural Exchange Program between the Ministry of Culture of the Tajikistan Republic and the Ministry of Culture of the People's Republic of China for the Years 2005 to 2009 in May 2005, providing that cultural organizations of the two countries are supposed to have extensive exchange, organize exhibitions of fine arts and practical adornment art, hold cultural festivals, and broadcast art films and documentary films of other countries. In 2004, 30 teachers and students from Sarsen Amanzholov East Kazakhstan State University participated in the 4th "Jin Shan Zhi Xia" Arts Festival in Altay in Xinjiang. In November 2007, an 18-person group of young artists from Астана Music Theatre inKazakhstan came over to Kazak Autonomous Prefecture in Ili in Xinjiang for exchange with young artists in Xinjiang and performance. In 2007, in the efforts of Tajikistan Association for Friendship with Foreign Countries and Cultural Exchange, Tajikistan artists held a concert in the Tianqiao Theatre in Beijing, and more than 20,000 Beijing citizens watched the concert and exhibition. Meanwhile, the Twelve Muqam, Uigurian dance, songs, craftsmanship and Kazak handicrafts have been displayed in Central Asian countries many times. The large national dance drama-Rain of Flowers on the Silk Road created by Gansu Dance Troupe by absorbing elements of Dunhuang music and dance to show the friendship between China and western businessmen in the Tang Dynasty (reflecting the western characteristics in respect of dance and uniform) was performed twice in the Bishkek National Opera House in October 2013, more than 2000 persons watched the performances, and it caused great repercussions. In 2016, Gansu province organized performance of the Rain of Flowers on the Silk Road and the Dreaming of Dunhuang in the Eve of the Lunar New Year in Central Asia and Western Asia, enjoying warm welcome and high evaluation.

China and Central Asia have achieved a good start of artistic exchange, and are expected to have a broad exchange and cooperation space. There are art markets and artistic consumption demands in both regions. But we haven't had a full understanding of advantages and functions of artistic exchange, haven't made enough efforts, and lack a scientific and systematic design. Firstly, Central Asian countries' problems in cultural industry development include insufficient infrastructure, and unfavorable hardware condition. It will take a certain period for them to construct a sound art culture industry system. Thus, their conditions for cultural and artistic exchanges are unfavorable for a time. Besides, Central Asian countries don't attach enough importance to transnational artistic exchange, and also haven't made detailed policies and regulations. Secondly, relative to the developed countries in the west, China started late in culture industry development. Although China's cultural investment covers many countries and regions in the world, it lacks rational and scientific profession system and standard system on external cultural export and investment and high-quality products, which, together with poor communication and insufficient government support, poses barriers for Chinese cultural enterprises' development in the international market. Thirdly, artistic exchange needs to be further enhanced in respect of width and depth. China and Central Asian countries have exchanges and cooperation in film, drama, sculpture, acrobatics and music, but the cooperative relationships are not close enough. Such cooperation activities usually were held at certain time, so that the activities are not impressive enough. There are a lot of limitations, and the masses' needs cannot be met. Besides, the artistic exchange between China and Central Asia also needs to be further enhanced.

\section{Construction of Sino-Central Asia Artistic Exchange Mechanism in All-round Way}

The "Silk Road" mainly aims to realize multi-cultural coexistence, exchange and development, in which it is advocated to respect different cultures and values, promote mutual understanding, prevent 
narrow nationalism, and provide a basic guarantee and solid foundation for economic cooperation and political mutual trust among the countries along the road. It is an important way for China to implement "harmonious diplomacy" and "cultural diplomacy".

To construct Sino-Central Asia artistic exchange mechanism, it is supposed to conform to the theories of inter-subject exchange and interactive cooperation, comprehensively analyze the current situation and problems of exchange, determine artistic content and type suitable for Central Asia for exchanges, select a proper and effective exchange pattern, and carry out mechanism construction, including system design, legal protection, mechanism design, idea bank construction and other measures for "top-level design"; make full use of the geographic advantages of the northwest district of China and Central Asia, the similarity in ethnics, culture and religion, and communication that can arouse cultural and spiritual resonance. Secondly, the state or related organizations are supposed to coordinate the links of exchange designedly via administrative means, establish various platforms, make great efforts in constructing private support system, actively push forward the operation mode of commercial capitalization, make full use of traditional media and new media technologies, and construct a scientific, systematic, multi-layered, multi-path and two-way exchange mode; enhance cultural exchange and cooperation in film, music, painting, martial art, design and dance according to the cultural characteristics and advantages of Central Asian countries, strengthen interactions and exchanges between youths of the countries, and invite youths of the countries along the road to participate. Besides, the popular television programs such as "Let's Shake It", "A Bright World", "Talent", "Let It Go" and so on can be made use of, recruiting competitors from the countries along the road and providing platforms for youths of the countries along the road to have skill competition and mutual understanding. Besides, it is feasible to encourage social organizations and various cultural groups to undertake cultural exchange program, and strive to obtain the force of overseas studentsand overseas Chinese as the link to enhance affective interactions with these countries. It is also feasible to cooperate with these countries in filming videos on local conditions and customs of these countries, to influence people of these countries via cultural works.

Lastly, it needs to be noted that the two-way symmetric principle is the basic principle to be followed in artistic exchange between China and Central Asia. The export and import of artistic works are equally important. Active import is good for export. The active import of Central Asian art doesn't only meet the needs of Chinese people, but is the best way of equal communication, goodwill expression and suspicion elimination. There is a good history foundation for cultural and educational exchange between China and Central Asia, and an important real opportunity comes. Art is the essence of ethnic culture expected by both sides most. The northwest region of China and Central Asia share many things in common, including ethnics, religion, and history, having the natural advantages for artistic exchange. To realize the objectives of artistic exchange between China and Central Asia, we should grasp the overall situation, reach a high policy theory level, design an orderly operation procedure and construct a scientific and effective exchange mechanism.

\section{Acknowledgement}

This paper is supported by the Scientific Research Project of College and Universities in Gansu Province (General Project): Study on Chinese Teaching in Central Asia under the Context of Westward Opening up, 2014, Project No.: 2014A-025, Social Science Backbone Project of Northwest Normal University: Study on Language Competition among Central Asian Countries and Chinese Communication Strategy, 2015. Project No.: SKGG15020.

\section{References}

[1] History of Sui Dynasty, Volume 15, Music Record, Zhonghua Book Company, 1973, P378. (1)

[2] Yuan Dynasty, Yang Yu, Shan Ju Xin Yu, Volume 2, Notes Collection of Historical Data of the Yuan and Ming Dynasties, Zhonghua Book Company, 2006, P212. 
[3] Shen Aifeng, From the Lazurite Road to the Silk Road-Trace to the Source of Ancient Art in Western Asia, Central Asia, and Eurasian Prairie, Volume II, Shandong Fine Arts Publishing House, 2009, P519.

[4] Jiang Boqin, Dunhuang Art-Religion and Civilization of Etiquette and Music, China Social Sciences Publishing House, 1996, P158-165.

[5] Russia, Marshak, Nigel Mato, Sogdiana, excerpted from f (Russia) Chapter X of Volume III of the History of Civilization of Central Asia chiefly edited by Б. A. LitVinsky, China Translation and Publication Corporation, 2003, P209.

[6] Al-Tha'ālibi, Book of Tidbits and Jocularities, quoted from Zhou Yiliang's History of Sino-foreign Cultural Exchanges, Zhengzhou: Henan People's Publishing House, 1987, P760.

[7] A bū, l-Faraj al-Isfahānī: Kitāb al-Aghān̄̄, quoted from Zhou iliang's History of Sino-foreign Cultural Exchanges, Zhengzhou: Henan People's Publishing House, 1987, P775. 